\title{
Feeding ecology of Parapenaeus longirostris (Lucas, 1846) (Decapoda: Penaeidae) from the Ionian Sea (Central and Eastern Mediterranean Sea)*
}

\author{
KOSTAS KAPIRIS \\ Institute of Marine Biological Resources, Hellenic Centre for Marine Research, Agios Kosmas, 166 04, Hellinikon, \\ Greece. E-mail: kkapir@ncmr.gr
}

\begin{abstract}
SUMMARY: The purpose of this paper is to investigate the feeding habits of Parapenaeus longirostris in the Greek and Italian Ionian Sea. The individuals were caught from September 1999 to July 2000 on a seasonal basis (except winter) in the Greek Ionian Sea, and in August 2000 in the Italian Ionian Sea. A total of 324 males and 309 females of P. longirostris were analysed. A comparative analysis of the diet and feeding activity was made, taking into account sex, season, size classes and study area as factors influencing the feeding habits of the species. Dietary diversity was also estimated. P. longirostris displayed a high feeding preference on a large variety of bathypelagic, benthic and endobenthic preys, mainly polychaetes, crustaceans and molluscs. No clear differentiation in the feeding behaviour between sexes, including diet composition and feeding activity, was observed. The increased feeding activity during spring for males and spring-summer for females could possibly be attributed to metabolic processes. This species undergoes changes in its feeding habits with ontogeny. Larger specimens were more efficient predators than smaller ones, possibly because of their greater swimming ability. The increased feeding activity in the Italian Ionian Sea is possibly related to the different environmental conditions.
\end{abstract}

Key words: Parapenaeus longirostris, diet, feeding activity, ontogeny, Ionian Sea.

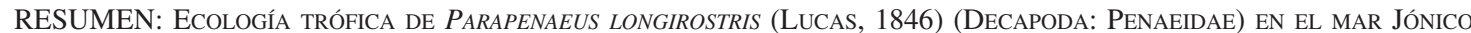
(MEDITERRÁNEO CENTRAL Y ORIENTAL). - En el presente trabajo se estudian los hábitos alimenticios de Parapenaeus longirostris en el Mar Jónico de Grecia e Italia. En el Mar Jónico de Grecia, las muestras fueron recolectadas estacionalmente desde Septiembre 1999 hasta Julio 2000 (excepto en invierno), mientras que en el mar Jónico de Italia sólo se recolectaron en Agosto 2000. En total, 324 estómagos de machos y 309 de hembras fueron examinados. El análisis comparativo de dieta y de la actividad alimentaria se realizó teniendo en cuenta el sexo, la clase de talla y el área de estudio. Además, se examinó la diversidad de la dieta. P. longirostris mostró preferencia respecto a una gran variedad de presas batipelágicas, bentónicas y endobentónicas, principalmente poliquetos, crustáceos y moluscos. No se encontró una clara diferenciación en la dieta y la actividad alimentaria entre los sexos. La alta actividad alimentaria en primavera para los machos y en primaveraverano para las hembras pueden ser relacionadas con procesos metabólicos. La especie mostró cambios ontogenéticos en sus hábitos alimentarios. Los grandes individuos se han presentado como predadores más eficaces que los pequeños, probablemente relacionado con su mayor capacidad natatoria. La mayor actividad alimentaria en el área italiana se encuentra posiblemente relacionada con las condiciones ambientales.

Palabras clave: Parapenaeus longirostris, dieta, alimentación, ontogenia, Mar Jónico.

\section{INTRODUCTION}

The rose shrimp Parapenaeus longirostris (Lucas, 1846) shows a wide geographic distribution,

*Received April 24, 2003. Accepted November 21, 2003. being found in the eastern Atlantic from northern Spain (Olaso, 1990) to the southern waters of Angola (Sobrino and Cardenas, 1996; Crosnier and Forest, 1973; Holthuis, 1980) and the whole basin of the Mediterranean and its adjacent seas (the Thyrrenian, Adriatic, Aegean and the Sea of Marmara) (Maurin, 
1960; Massuti, 1963; Audouin, 1965; Koukouras and Kattulas, 1974; Holthuis, 1980).

In the Mediterranean Sea, the species inhabits sand-mud $\$$ bottoms and its bathymetric distribution ranges between 20 and $750 \mathrm{~m}$ (Tom et al. 1988). However, its main distribution stratum is between 100 and 400 m (Ribeiro Cascalho, 1988; Sobrino, 1988; Sobrino and Fernandez, 1991; Crosnier et al., 1970; Crosnier and Forest, 1973).

This epibenthic short-lived species is the main target species of a large fishing fleet working in the eastern Atlantic Ocean and is characterised by high rates of growth and mortality (Abelló et al., 2002). The principal fishing grounds are located in the south of Spain and Portugal (Pestana, 1991; Sobrino et al., 1994, 2000), as well as areas off Morocco, Mauritania, Senegal, Guinea Bissau, Gabon and Angola (Cervantes and Goñi, 1986; Cervantes et al., 1991; Sobrino and García, 1991, 1992a,b). The species also has a high commercial value in France, Italy, Algeria, Tunisia, Greece and Turkey, although on a lesser scale (Stamatopoulos, 1993).

Because of its great economic importance, a lot of information exists on the biology and ecology of this species. For the last twenty years in the Mediterranean Sea, this species has been the subject of important studies allowing the collection of detailed information on distribution (e.g. Ardizzone et al., 1990; D’Onghia et al., 1998; Mori et al., 1986; Tom et al., 1988), abundance (e.g. Levi et al., 1995; Lembo et al., 2000; Pestana, 1991; Sobrino et al., 2000; Nouar and Maurin, 2001) and biology (e.g. Arrobas and Ribeiro Cascalho, 1982; Ribeiro Cascalho and Arrobas, 1983, 1987; Lagmari et al., 2001; Dos Santos, 1998; Spedicato et al., 1996; Mori et al., 1986; De Ranieri et al., 1998; Froglia, 1982; Sobrino and Garcia, 1994). In the eastern Mediterranean Sea there are few studies on its biology, and knowledge of the fishery of this species was only recently obtained in the framework of trawl survey projects carried out principally in deep waters (Anon., 1999; Anon., 2001, 2003; Politou et al., 1998; Abelló et al., 2002; Kapiris et al., 2002).

Despite its biological importance, very few studies have been conducted on its feeding habits in the western and central Mediterranean (Orsi Relini, 1973; Ribeiro Cascalho and Arrobas, 1983; Burukovsky, 1969; Mori et al., 2000; Cartes, 1995). Labropoulou and Kostikas (1999) have studied the distribution patterns and the feeding habits of four deep-water decapods-including P. longirostris- caught along the continental slope of Crete (South Aegean Sea).

The present work aims to contribute to the knowledge of the diet and feeding habits of this species occurring in the North Ionian Sea (Greek and Italian sectors) and to assess the effects of season, sex, size and region on its diet.

\section{MATERIAL AND METHODS}

In the framework of the Interreg II project (Greece-Italy), three seasonal surveys (September 1999, April 2000, July 2000) were carried out along the Greek coasts of the North Ionian Sea between Othoni Island and the Island of Zakynthos at depths ranging from 300 to $1200 \mathrm{~m}$, and one survey was carried out in the Italian Ionian Sea (August 2000) (Fig. 1). In both study areas the species was more abundant in the depth zone from 300 to $500 \mathrm{~m}$. Stratified sampling was used and a total of 60 hauls were carried out during each survey in the Greek study area and 29 in the Italian one. A commercial 159 ton vessel with a 923 HP engine equipped with a trawl of $40 \mathrm{~mm}$ stretched mesh size at the cod-end was hired.

The samples were fixed on board immediately after capture in $10 \%$ buffered formalin. A total of 324 male and 309 female stomach contents of $P$. longirostris were analysed. The carapace length (CL) and the body weight (BW) were registered. The stomach was removed and the weight of the stomach content was determined (SC). Prey items were identified to the lowest taxonomic level possible and counted under a binocular stereoscope.

The vacuity index (VI, empty stomachs/total number of stomachs*100) was estimated. The stomach fullness was recorded in two different ways: (a) as a percentage using the scale empty $(0-10 \%)$, moderately full (11-40\%), full (41-70\%) and very full (71-100\%); and (b) using the repletion index (RI) (SC/BW*100) (Morato et al., 2000).

The percent frequency of occurrence $(\mathrm{O})$ and the relative abundance (A) for each type of prey were calculated for each stomach (Hyslop, 1980):

$\% \mathrm{O}=$ (number of stomachs containing a given prey item x 100)/total number of stomachs examined

$\% \mathrm{~A}=$ (number of prey items of a given prey $\mathrm{x}$ $100) /$ total number of prey items.

Fish, echinoderms and sipunculoidea items were counted as a single prey item per stomach, 


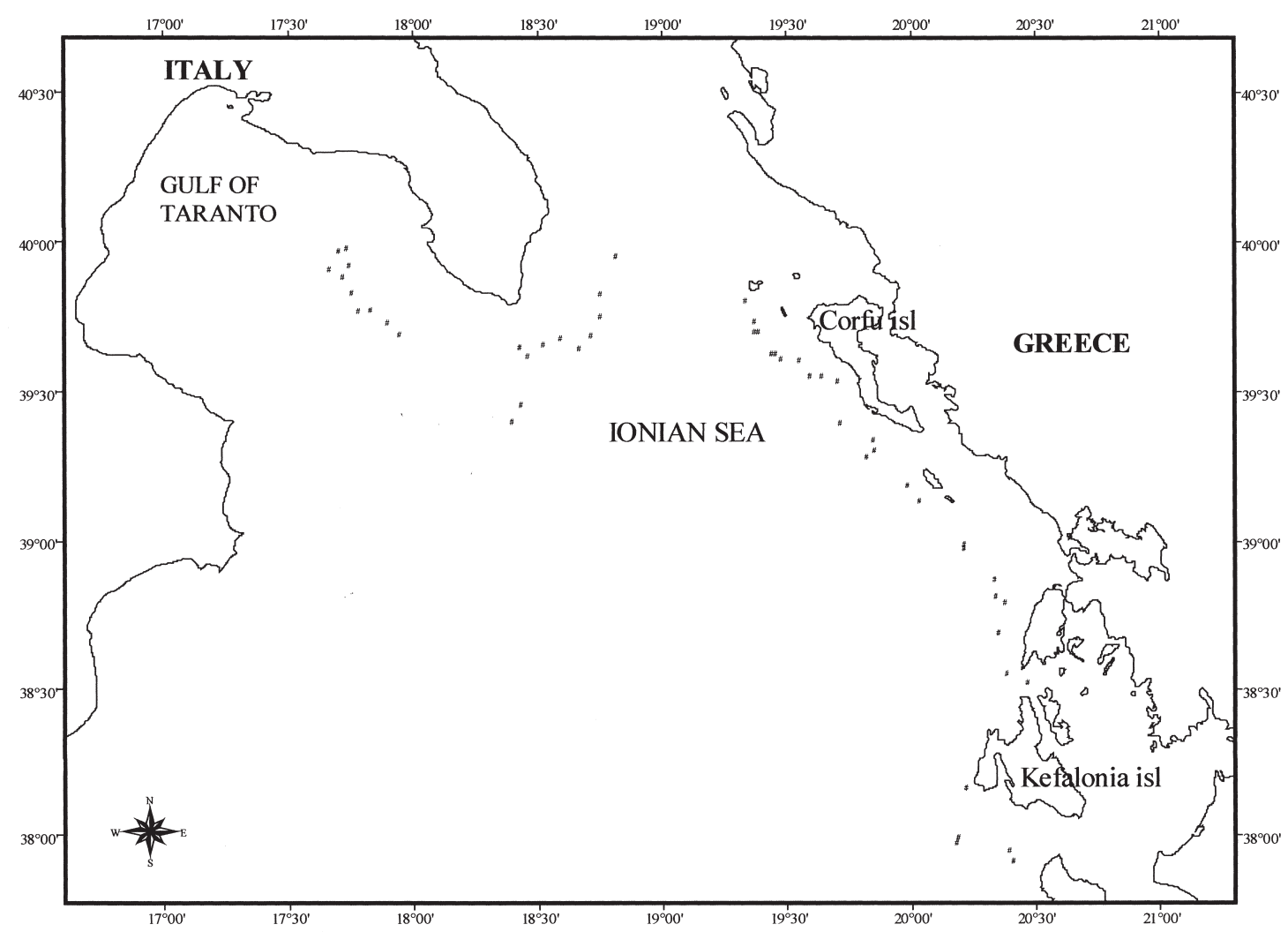

FIG. 1. - Map of the sampling area with the stations.

because it was not possible to distinguish the exact number of prey items. The unidentified molluscs and crustaceans were referred to as "mollusca" and "crustacea". Seeds and macrophytes were reported under the term "plant debris". The presence of scales was not taken as proof that fish had been eaten (Jutkins and Fleminger, 1972; Cartes and Sardà, 1989). We have called any amorphous soft portion that could not be identified as a taxon "nonidentified" preys .

To detect the variations related to the size and to the food habits, the individuals of both sexes of $P$. longirostris were separated into two size groups: those under $15 \mathrm{~mm}$ carapace length (CL), considered as "small" and those over $15 \mathrm{~mm}$ CL considered as "large".

Lastly, diversities in the diets of different sexes, size classes and seasons were established using the Shannon index (Shannon and Weaver, 1963) based on the numerical (relative) abundance of prey items found in the stomachs. In order to avoid bias due to the different areas studied, we distinguished the analysis of the data from each area (Greek and Italian Ionian Sea). A comparative study between the data from Italy and Greece was done between the August 2000 and September 1999 surveys respec- tively. The above comparison was carried out, in spite of the slight temporal difference, because of the high summer environmental stability of both study areas.

Statistical differences in dietary compositions and stomach fullness by size, sex, season and region were tested by the non parametric Mann-Whitney, Kruskall-Wallis, Kolmogorov-Smirnov tests (Sokal and Rohlf, 1981). We deemed only those independent variables with $\mathrm{P}<0.05$ to be significant.

\section{RESULTS}

The CL of the sampled individuals ranged from 7.98 to $37.40 \mathrm{~mm}$ [average: $20.72 \mathrm{~mm} \pm 5.54$ (standard deviation)] for the females and from 4.34 to $34.60 \mathrm{~mm}$ (average: $20.86 \pm 4.34 \mathrm{~mm}$ ) for the males. The body weight ranged from 0.33 to $21.88 \mathrm{~g}$ (average: $5.66 \pm 3.83 \mathrm{~g}$ ) for the females and from 1.30 to $20.22 \mathrm{~g}$ (average: $5.62 \pm 3.15 \mathrm{~g}$ ) for the males. There was no statistically significant difference between the median $\mathrm{CL}$ and body weight of males and females (Mann-Whitney test, $\mathrm{P}=0.69$ ). The size frequency distribution of both sexes is illustrated in Figure 2. 


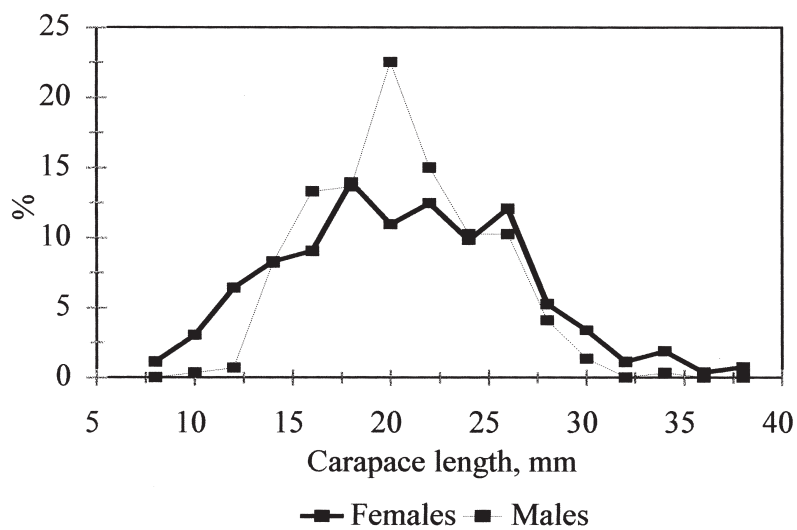

FIG. 2. - Length-frequency distribution of males $(\mathrm{N}=293)$ and females ( $\mathrm{N}=265)$ of Parapenaeus longirostris.

\section{Diet composition}

The diet composition of male and female P. longirostris per sampling season and study area is summarised in Tables 1 and 2. A total of 1045 food items belonging to 36 prey categories were identi- fied. Diet consisted mainly of polychaetes, crustaceans and gastropods. The diet of this species, according to the Shannon index, was highly diversified (Table 3).

In the Greek waters, the most important groups of prey items based on both the $\% \mathrm{~A}$ and $\% \mathrm{O}$ found in the stomachs of both sexes, were polychaetes, decapoda natantia, gastropods, amphipods and osteichthyes. For males, for all the sampling periods these five prey categories constituted $18.25-57.87 \%$ of the relative abundance and $18.9-57.22 \%$ of frequency of occurrence. For females, those values were $16.80-70.27 \%$ and $16.80-68.57 \%$ respectively. A statistically significant difference between seasonal medians of the relative abundance at $95 \%$ level was found only in females (Kruskall-Wallis, $\mathrm{P}=0.003$ ). Cephalopoda and nematoda were very common in the diet of both sexes during September, whereas aplacophora (mollusca), cephalopoda, eggs, tanaidacea, reptantia and mysidacea were present in the diet of both sexes only during this period.

TABle 1. - Diet composition of Parapenaeus longirostris males per sampling area and season. A: relative abundance, O: percent frequency of occurrence.

\begin{tabular}{|c|c|c|c|c|c|c|c|c|}
\hline \multirow{3}{*}{$\begin{array}{l}\text { Prey items } \\
\text { MOLLUSCA }\end{array}$} & \multicolumn{6}{|c|}{ Greek Ionian Sea } & \multicolumn{2}{|c|}{ Italian Ionian Sea } \\
\hline & \multicolumn{2}{|c|}{$\begin{array}{lc}\text { A } & \text { O } \\
\text { September } & 1999\end{array}$} & \multicolumn{2}{|c|}{$\begin{array}{l}\text { A } \\
\text { April } 2000\end{array}$} & \multicolumn{2}{|c|}{ July 2000} & \multicolumn{2}{|c|}{$\begin{array}{cr}\text { A } & \text { O } \\
\text { August } 2000\end{array}$} \\
\hline & 1.74 & 1.84 & & & 4.04 & 4.12 & 7.69 & 8.06 \\
\hline Aplacophora & 0.87 & 0.92 & & & & & & \\
\hline Bivalvia & 5.22 & 5.07 & 0.51 & 0.52 & & & 1.54 & 1.61 \\
\hline Gastropoda & 4.78 & 4.61 & 6.09 & 5.67 & 3.03 & 3.09 & 15.38 & 12.90 \\
\hline Scaphopoda & 4.78 & 5.07 & 0.51 & 0.52 & & & & \\
\hline Cephalopoda & 11.74 & 11.98 & 1.02 & 1.03 & 1.01 & 1.03 & & \\
\hline Molluscs eggs & 0.87 & 0.46 & & & & & & \\
\hline POLYCHAETA & 3.91 & 4.15 & 28.43 & 28.35 & 13.13 & 13.40 & 7.69 & 8.06 \\
\hline Sipunculoidea & 6.09 & 5.99 & 4.06 & 4.12 & 5.05 & 5.15 & 4.62 & 4.84 \\
\hline NEMATODA & 10.00 & 10.60 & & & 1.01 & 1.03 & & \\
\hline CRUSTACEA & 5.65 & 5.99 & 5.08 & 5.15 & 9.09 & 8.25 & & \\
\hline Decapoda Natantia & 5.65 & 5.99 & $12 . .69$ & 12.89 & 15.15 & 15.46 & 13.84 & 14.52 \\
\hline Brachyura & 0.87 & 0.92 & & 0.00 & & & & \\
\hline Amphipoda & 0.43 & 0.46 & 8.12 & 7.73 & 8.08 & 8.25 & 1.54 & 1.61 \\
\hline Isopoda & 0.43 & 0.46 & & & 2.02 & 2.06 & 1.54 & 1.61 \\
\hline Tanaidacea & 4.35 & 0.92 & & & & & & \\
\hline Cumacea & 1.74 & 1.84 & 0.51 & 0.52 & 2.02 & 2.06 & & \\
\hline Ostracoda & 0.87 & 0.92 & 1.02 & 1.03 & 2.02 & 2.06 & & \\
\hline Copepoda & 2.61 & 2.76 & 0.00 & & 1.01 & 1.03 & & \\
\hline Euphausiacea & 4.78 & 5.07 & 2.03 & 2.06 & 2.02 & 2.06 & & \\
\hline Mysidacea & 2.17 & 2.30 & & & & & & \\
\hline Decapoda Reptantia & 2.61 & 2.76 & 0.51 & 0.52 & & & & \\
\hline OSTEICHTHYES & 3.48 & 3.69 & 2.54 & 2.58 & 6.06 & 6.19 & 9.23 & 9.68 \\
\hline SCALES & 2.17 & 2.30 & 6.09 & 6.19 & 10.10 & 10.31 & 16.92 & 17.74 \\
\hline Non-identified fish & 0.87 & 0.92 & 4.57 & 4.64 & 1.01 & 1.03 & & \\
\hline FORAMINIFERA & 0.87 & 0.92 & 4.57 & 4.64 & 7.07 & 6.19 & 4.62 & 3.23 \\
\hline RADIOLARIA & & & 0.51 & 0.52 & & & & \\
\hline HYDROZOA & & & & & & & & \\
\hline ECHINODERMATA & 0.87 & 0.92 & & & & & 1.54 & 1.61 \\
\hline CHAETOGNATHA & & & & & & & 3.08 & 3.23 \\
\hline NON-IDENTIFIED & & & 0.51 & 0.52 & & & & \\
\hline MUD & & & & & & & & \\
\hline PLASTICS, OTHER & 1.30 & 1.38 & & & 3.03 & 3.09 & & \\
\hline Soft tissues & 3.91 & 4.15 & 1.52 & 1.55 & 3.03 & 3.09 & 10.77 & 11.29 \\
\hline Plant debris & 4.35 & 4.61 & 9.14 & 9.28 & 1.01 & 1.03 & & \\
\hline
\end{tabular}


TABLE 2. - Diet composition of Parapenaeus longirostris females per sampling area and season. A: relative abundance, O: percent frequency of occurrence.

\begin{tabular}{|c|c|c|c|c|c|c|c|c|}
\hline \multirow{3}{*}{$\begin{array}{l}\text { Prey items } \\
\text { MOLLUSCA }\end{array}$} & \multicolumn{6}{|c|}{ Greek Ionian Sea } & \multicolumn{2}{|c|}{ Italian Ionian Sea } \\
\hline & \multicolumn{2}{|c|}{$\begin{array}{l}\text { A } \\
\text { September } 1999\end{array}$} & \multicolumn{2}{|c|}{$\begin{array}{l}\text { A } \\
\text { April } 2000\end{array}$} & A & $\mathrm{O}$ & \multicolumn{2}{|c|}{$\begin{array}{cr}\text { A } & \text { O } \\
\text { August } 2000\end{array}$} \\
\hline & 1.16 & 1.20 & 3.07 & 2.78 & 5.41 & 5.71 & 6.25 & 6.67 \\
\hline Aplacophora & 0.58 & 0.60 & & & & & & \\
\hline Bivalvia & 5.78 & 4.19 & 2.19 & 2.31 & & & & \\
\hline Gastropoda & 5.78 & 5.39 & 14.47 & 10.65 & 5.41 & 2.86 & 18.75 & 13.33 \\
\hline Scaphopoda & 2.89 & 2.99 & 0.44 & 0.46 & & & & \\
\hline Cephalopoda & 19.08 & 19.16 & 0.88 & 0.93 & & & & \\
\hline Molluscs eggs & 0.58 & 0.60 & & & & & & \\
\hline POLYCHAETA & 2.31 & 2.40 & 19.74 & 20.83 & 24.32 & 25.71 & 12.5 & 13.33 \\
\hline Sipunculoidea & 2.89 & 2.99 & 2.63 & 2.78 & & & & \\
\hline NEMATODA & 9.83 & 10.18 & & & & & & \\
\hline CRUSTACEA & 4.62 & 4.79 & 5.70 & 6.02 & 8.11 & 8.57 & 6.25 & 6.67 \\
\hline Decapoda Natantia & 5.20 & 5.39 & 10.96 & 11.57 & 32.43 & 31.43 & 6.25 & 6.67 \\
\hline Brachyura & 0.58 & 0.60 & 1.75 & 1.85 & & & 6.25 & 6.67 \\
\hline Amphipoda & 0.58 & 0.60 & 4.82 & 5.09 & 5.41 & 5.71 & & \\
\hline Isopoda & & & 1.32 & 1.39 & 5.41 & 5.71 & & \\
\hline Tanaidacea & 0.58 & 0.60 & & & & & & \\
\hline Cumacea & 1.73 & 1.80 & & & & & & \\
\hline Ostracoda & 2.89 & 2.99 & 0.44 & 0.46 & & & & \\
\hline Copepoda & 4.05 & 4.19 & & & & & & \\
\hline Euphausiacea & 7.51 & 7.78 & 2.19 & 2.31 & 2.70 & 2.86 & & \\
\hline Mysidacea & 1.16 & 1.20 & 1.32 & 1.39 & & & & \\
\hline Decapoda Reptantia & 2.89 & 2.40 & & & & & & \\
\hline OSTEICHTHYES & 2.31 & 2.40 & 1.32 & 1.39 & 2.70 & 2.86 & 6.25 & 6.67 \\
\hline SCALES & 2.31 & 2.40 & 5.26 & 5.56 & 2.70 & 2.86 & 6.25 & 6.67 \\
\hline Non-identified fishes & 1.16 & 1.20 & 3.95 & 4.17 & & & 6.25 & 6.67 \\
\hline FORAMINIFERA & 0.58 & 0.60 & 6.14 & 6.48 & & & 12.5 & 13.33 \\
\hline RADIOLARIA & & & 2.19 & 1.85 & & & & \\
\hline HYDROZOA & 0.58 & 0.60 & 0.44 & 0.46 & & & & \\
\hline ECHINODERMATA & & & & & & & 6.25 & 6.67 \\
\hline CHAETOGNATHA & 0.58 & 0.60 & & & & & & \\
\hline NON-IDENTIFIED & 0.58 & 0.60 & 1.32 & 1.39 & & & & \\
\hline MUD & 0.58 & 0.60 & & & & & & \\
\hline PLASTICS, OTHER & 0.58 & 0.60 & & & & & & \\
\hline Soft tissues & & & 5.70 & 6.02 & 5.41 & 5.71 & 6.25 & 6.67 \\
\hline Plant debris & 8.09 & 8.38 & 1.75 & 1.85 & & & & \\
\hline
\end{tabular}

TABle 3. - Trophic mean diversity of Parapenaeus longirostris by study area and sex according to the Shannon index.

\begin{tabular}{lccc}
\hline \multirow{2}{*}{ Study area } & \multirow{2}{*}{$\begin{array}{c}\text { Sampling } \\
\text { period }\end{array}$} & Males & Females \\
& & & \\
\hline \multirow{2}{*}{ Greek Ionian Sea } & SEP/1999 & 1.47 & 1.50 \\
& APR/2000 & 1.38 & 1.43 \\
Italian Ionian Sea & JUL/2000 & 1.36 & 1.07 \\
& AUG/2000 & 1.17 & 1.04 \\
\hline
\end{tabular}

In spring, the most important prey were polychaetes, plant debris and amphipods for males, and polychaetes, gastropods and decapods for females. In July, the dominant prey items were polychaetes, decapods and fish for males, and decapods and polychaetes for females. In each season, no statistically significant difference was found in the diet composition between males and females (Mann-Whitney, $\mathrm{P}=0.35$ ). The trophic diversity (Table 3 ) was found to be indifferent between seasons in both sexes (Mann-Whitney test, $\mathrm{P}=0.88$ ). It was found to increase in September 1999 for both sexes, confirming a higher dietary specialisation during autumn.

In the Italian waters, the composition of the diet of both sexes of $P$. longirostris included osteichthyes, gastropods and soft tissues in males, and gastropods, foraminifera and polychaetes in females. In contrast, some crustaceans, such as amphipoda, isopoda, ostracoda, euphausiacea and mysidacea were secondary food items. It is worth noting that there was no statistically significant difference between the medians of the relative abundance of the prey items between the Italian Ionian Sea (August 2000) and the Greek study areas (September 1999) for either sex (Mann-Whitney, $\mathrm{P}=0.89$ for females and 0.57 for males). However, the prey distributions were statistically different between the two study areas (Kolmogorov-Smirnov, $\mathrm{P}=0.00$ for both sexes). Thus, gastropods, foraminifera, polychaetes, fishes and molluscs were more frequent in stomach contents in specimens caught in the Italian Ionian Sea than in Greek waters. No statistically sig- 
TABLE 4. - Mean values ( \pm standard deviation) of stomach content weight $(\mathrm{SC}, \mathrm{g})$, repletion index (RI, \%), stomach fullness $(\mathrm{F}, \%)$ and vacuity index (VI, \%) of Parapenaeus longirostris by study area and sex.

\begin{tabular}{|c|c|c|c|c|c|c|}
\hline Study area & Sampling period & Sex & $\mathrm{SC}(\mathrm{g})$ & RI (\%) & $\mathrm{F}(\%)$ & VI (\%) \\
\hline Greek Ionian Sea & $\begin{array}{l}\text { SEP/1999 } \\
\text { APR/ } 2000 \\
\text { JUL/ } 2000\end{array}$ & $\begin{array}{l}\mathrm{M} \\
\mathrm{F} \\
\mathrm{M} \\
\mathrm{F} \\
\mathrm{M} \\
\mathrm{F}\end{array}$ & $\begin{array}{l}0.024 \pm 0.012 \\
0.027 \pm 0.011 \\
0.030 \pm 0.014 \\
0.034 \pm 0.017 \\
0.035 \pm 0.019 \\
0.048 \pm 0.023\end{array}$ & $\begin{array}{l}0.49 \pm 0.31 \\
0.52 \pm 0.27 \\
0.85 \pm 0.52 \\
0.80 \pm 0.47 \\
0.51 \pm 0.31 \\
0.69 \pm 0.45\end{array}$ & $\begin{array}{l}36.5 \pm 30.3 \\
34.2 \pm 22.4 \\
45.8 \pm 30.4 \\
36.5 \pm 228 \\
52.4 \pm 31.7 \\
36.9 \pm 20.6\end{array}$ & $\begin{array}{l}22.6 \\
28 \\
10.5 \\
8.1 \\
2.7 \\
25\end{array}$ \\
\hline Italian Ionian Sea & AUG/ 2000 & $\begin{array}{c}\mathrm{M} \\
\mathrm{F}\end{array}$ & $\begin{array}{l}0.14 \pm 0.009 \\
0.11 \pm 0.054\end{array}$ & $\begin{array}{l}1.19 \pm 0.62 \\
0.56 \pm 0.26\end{array}$ & $\begin{array}{r}43.7 \pm 27.1 \\
54 \pm 27.6\end{array}$ & $\begin{array}{l}16.6 \\
16\end{array}$ \\
\hline
\end{tabular}

nificant difference was found between the diet composition of males and females in the Italian study area (Mann-Whitney, $\mathrm{P}=0.43$ ). The diversity index in the Italian study area (Table 3) was much lower than that estimated for the Greek study area (September 1999).

\section{Feeding activity}

The median stomach content weight did not differ significantly between the two sexes (MannWhitney, $\mathrm{P}=0.10$ ) in the Greek Ionian Sea in each season (Table 4). However, the females' stomach content weight was higher than that of males for each sampling period. Significant differences between the seasonal medians were found for both sexes (Kruskall-Wallis, $\mathrm{P}=0.01$ ). The highest stomach content weight was found in July and the lowest in September for both sexes. In the Italian Ionian Sea, the stomach content weight was statistically higher than that found in the Greek waters for both sexes (September 1999) (Mann-Whitney, $\mathrm{P}=0.002$ for females and $\mathrm{P}=0.00$ for males).

The mean seasonal repletion index and the standard deviation are given in Table 4. Statistically significant differences between the seasonal medians were found for both sexes (Kruskall-Wallis, $\mathrm{P}=0.00$ ). The highest value was found in April and the lowest in September for both sexes. In April, the species consumed heavier prey items such as gastropods, polychaetes and decapods (Tables 1 and 2). No significant difference between the mean repletion index was found between sexes (Mann-Whitney, $\mathrm{P}=0.47$ ).

The mean seasonal values and the standard deviation of the percentage scale of stomach fullness are also given in Table 4 . In this case, no significant difference between seasonal medians was found in either sex (Kruskall-Wallis, $\mathrm{P}=0.02$ ). The highest value was found in July and the lowest in September for both sexes. In the Italian Ionian Sea, the repletion index and the fullness values were higher than those found in the Greek waters (September 1999), but these differences were not significantly different (Mann-Whitney, $\mathrm{P}=0.67$ ).

The vacuity index was analysed per sex and season (Table 4). Empty stomachs were found in all seasons, although the highest proportion was found in September for both sexes. On the other hand, the lowest number of empty stomachs (highest proportion of non-empty stomachs) was found in July for males and in April for females. The percentage of empty stomachs for both sexes of $P$. longirostris in the Italian Ionian Sea was lower than that in the Greek Ionian Sea (September 1999), indicating that in the former area-in combination with the above results-the species exhibits better feeding opportunities.

The above results suggest that males have a higher feeding activity during summer (highest value of stomach content weight and fullness, high value of repletion index and lowest value of vacuity index), whereas in autumn their feeding activity is lower (lowest value of stomach content's weight, repletion index, fullness, highest value of vacuity index). Concerning females, the above results indicated that their feeding activity increased in spring (highest value of repletion index, high value of fullness, lowest value of vacuity index) and summer (highest fullness and stomach content weight). In September, both sexes showed a reduced feeding activity in relation to the other seasons (lowest value of stomach content's weight, repletion index, fullness, highest value of vacuity index).

\section{Feeding activities in relation to size}

The diet composition (relative abundance) per size group and sex (in pooled data) for P. longirostris is illustrated in Figure 3. The most common prey items of small male class individuals $(C L<15$ 

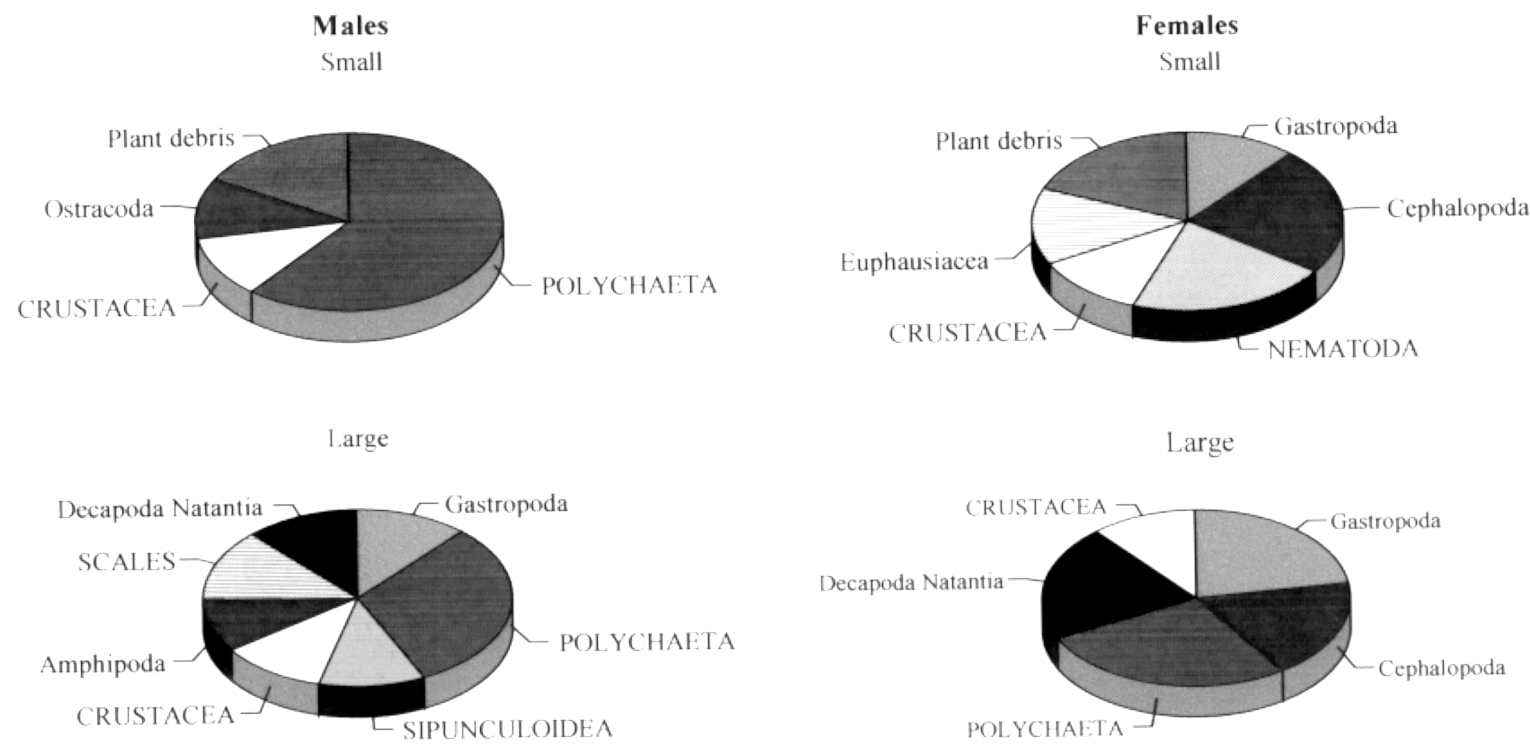

FIG. 3. - Diet composition (relative abundance) per size group and sex of Parapenaeus longirostris.

$\mathrm{mm}$ ) were polychaetes, crustaceans-mainly ostracods - and plant debris ( $72 \%$ of the total diet). In the case of females of the same class, cephalopoda, nematoda, crustacean (mainly euphausiacea) and plant debris (almost $50 \%$ of their total diet) prevailed. On the other hand, more mobile items predominated in the stomachs of the individuals of both sexes belonging to the larger size class $(C L>15$ $\mathrm{mm})$. Prey items such as decapoda natantia, osteichthyes and crustaceans were present in higher proportions (46-55\% of their total diet), indicating their higher predatory activity (Fig. 3). The diversity of the stomach content of the large individuals was statistically higher than that of the small ones, in both sexes (Mann-Whitney test $\mathrm{P}=0.002$ for males and $\mathrm{P}=0.03$ for females) (Table 5).

The stomach content weight, the repletion index, and the stomach fullness were significantly different between the smaller and larger individuals in both sexes, being higher in the larger individuals (Table 5). Thus, the $P$ values estimated by the Mann-Whitney test were always smaller than $0.05: \mathrm{P}=0.00$ for the stomach content weight, $\mathrm{P}=0.00$ for the repletion index and $\mathrm{P}=0.02$ for the fullness. On the other hand, the vacuity index was higher in the smaller ones (Table 5). It is worth noticing that the repletion index of the small males was statistically lower than that of the small females (Mann-Whitney test, $\mathrm{P}=0.02$ ). This could be attributed to the heavier prey items consumed by females (e.g. gastropods, cephalopods) (Fig. 3). On the other hand, no statistically significant difference in repletion index was shown between large males and females (MannWhitney test, $\mathrm{P}=0.00$ ).

\section{DISCUSSION}

Parapenaeus longirostris displayed a highly diversified diet and consumed a broad range of prey items. The present study showed that $P$. longirostris can be considered as an active carnivorous predator on bathypelagic, benthic and endobenthic preys, mostly polychaetes. The relative small proportion of osteichthyes and cephalopods in its diet suggests that scavenging is a secondary activity in the feed-

TABLE 5. - Mean values ( \pm standard deviation) of stomach content weight $(\mathrm{g})$, repletion index (RI, \%), stomach fullness (F, \%), vacuity index (VI, \%) and diversity (H') of Parapenaeus longirostris by size class.

\begin{tabular}{|c|c|c|c|c|}
\hline \multirow[t]{2}{*}{ Factor } & \multicolumn{2}{|c|}{ Females } & \multicolumn{2}{|c|}{ Males } \\
\hline & Small & Large & Small & Large \\
\hline $\mathrm{SC}(\mathrm{g})$ & $0.015 \pm 0.08$ & $0.039 \pm 0.012$ & $0.011 \pm 0.07$ & $0.050 \pm 0.017$ \\
\hline RI $(\%)$ & $0.65 \pm 0.22$ & $1.01 \pm 0.45$ & $0.53 \pm 0.26$ & $0.70 \pm 0.33$ \\
\hline $\mathrm{F}(\%)$ & $33.25 \pm 27.1$ & $36.7 \pm 23.5$ & $20.55 \pm 14.1$ & $38.01 \pm 27.5$ \\
\hline VI (\%) & 20 & 18.9 & 29.6 & 13.9 \\
\hline $\mathrm{H}^{\prime}$ & $0.83 \pm 0.33$ & $1.37 \pm 0.72$ & $1.29 \pm 0.42$ & $1.34 \pm 0.51$ \\
\hline
\end{tabular}


ing habits of $P$. longirostris. This is in accordance with the results of a similar study along the continental slope of Crete Island (Aegean Sea) (Lambropoulou and Kostikas, 1999).

The results presented here are in agreement with previous studies, taking into consideration the possible differences in the fauna and bottom morphology observed in each study area. Ribeiro Cascalho and Arrobas (1983) examined the stomach contents of 40 specimens of $P$. longirostris in southern Portugal. According to this study, fish, crustaceans (Decapoda, Cirripedia and Ostracoda), polychaetes and foraminifera seemed to be the preferential preys. In the Italian waters, Mori et al. (2000) reported that the prey items of this species consisted mostly of external skeletons of bottom organisms that were always crushed and often in an advanced state of deterioration. In addition, some inorganic material was found. Crustaceans, mainly mysids and amphipods, dominated the diet both qualitatively and quantitatively in specimens caught in the above area. Molluscs, represented mostly by juvenile bivalves and gastropods, cephalopods, small echinoderms (ophiuroids, sea urchins and holoturoids), polychaetes, fish, foraminifera and organic detritus were also found. During the hunting phase, $P$. longirostris feeds on small fish, cephalopods and crustaceans, while in a digging phase it searches for preys in the mud, such as polychaetes, bivalves, echinoderms and mostly foraminiferans (Orsi Relini, 1973).

The diversity index values in the Greek study area did not yield significant differences between seasons. The diet of this species showed only minor changes with season, probably because of the high environmental stability of the deep waters (Pérès, 1985). It is worth noting that the food diversity was higher in autumn, when a substantial increase in prey items that live buried in the substratum, such as tanaidacea and nematodaor scaphopoda, were observed in their stomachs. This suggests that the rooting behaviour of this species appears to be more intense in autumn. The diversity index $\mathrm{H}^{\prime}$ for the diet of $P$. longirostris was similar to that estimated in the Cretan Sea (Labropoulou and Kostikas, 1999), but much lower than that of the Catalan Sea (Cartes, 1995). However, these differences could be attributed to the different taxonomic identification level of prey of the above studies.

Feeding intensity, according to Bowman and Bowman (1980), is positively related to the repletion index and fullness and negatively related to the vacuity index. In the present study the low values of the vacuity index throughout the sampling period and the "moderately full" or "full" stomachs indicate that feeding intensity is high for P. longirostris. In the Catalan Sea, Cartes (1995) reported that the high fullness of the stomachs of this species could be attributed to the calcified preys it consumes, because these preys show a higher retention time in their foregut. In general, these features seem to apply to all the Penaeoidea, which are probably related to a random hunting strategy (Lagardère, 1972) and to a high metabolic rate, as demonstrated for Aristeus antennatus (Company, 1995; Maynou and Cartes, 1997).

No clear differentiation in the feeding behaviour in terms of either diet composition or feeding activity between sexes was observed. In addition, the increased values of the stomach content weight, the repletion index, the fullness and the low value of the vacuity index support the finding that feeding activity increases in summer for males and in spring or summer for females. This increase could be attributed to the metabolic processes of this species, such as reproduction, moulting and the settlement of juveniles (Dall et al., 1990). There are no data on the biological factors affecting the life cycle of $P$. longirostris in the study areas. However, the peak of gonad maturity is observed in autumn (unpublished data). Enlargement of the gonad compresses the stomach in females, thus preventing maximum stomach fullness. In fact, the feeding activity of both sexes was low during this period (lowest values of stomach contents weight, repletion index, fullness, highest percentage of empty stomachs). Notwithstanding, these trophic variations of $P$. longirostris would be an appropriate subject for future work.

Several studies on the diet of decapods highlight ontogenetic changes as the most important biotic factor in the diet variability. For example, the crab $\mathrm{Nec}$ ora puber shows increased preference for fish and decapods with growth and reduces the predation on non-decapod crustaceans and plants (Freire and González-Gurriarán, 1995). In general, an increase in the predator size means that the prey size will increase (Dall et al., 1990). Comparison of the diet composition, dietary diversity and feeding activity between the small and large individuals reveals that this species undergoes changes in its feeding habits with ontogeny. Larger specimens are more efficient predators than smaller ones because of their greater swimming ability. However, almost the same prey occurred in the stomachs of small and large specimens, but in different proportions. Studies made by 
Burukovsky (1969) in samples from the Gulf of Cadiz and off the northwest African coast indicate different diets according to age. According to this study, the diet of younger individuals consisted mainly of foraminifera and planktonic crustaceans. The analysis of foregut contents of older individuals showed that they consumed mostly amphipods, isopods, shrimps, crabs, euphausiids, mysids, some cephalopods and fish. No important differences were observed in the diets of the two $P$. longirostris size classes caught in the Catalan Sea (Cartes, 1995), but diet differences in different size groups in other deepwater natantian decapods (e.g. Aristeus antennatus (Cartes and Sardà, 1989) for Plesionika heterocarpus (Labropoulou and Kostikas, 1999), Aristaeomorpha foliacea (Cartes, 1995)) or reptantian decapods (e.g. Polycheles typhlops and Stereomastis sculpta (Cartes and Abelló, 1992)) have been reported.

No differences in the diet composition were found between the samples caught in the Greek and Italian study areas. All major taxa were present in the diet of individuals caught from both areas. The feeding activity of the individuals caught in the Italian study area, however, seems to be higher in the same period. These variations could be attributed to the different environmental conditions and biogeographic distribution occurring in the two areas. There are few available data on macrofaunal densities that would allow comparison between the two study areas. The type of bottom in the northwestern Ionian Sea (Italy) is more variable (sandy, rocky, coarse debris, sandy-mud, muddy) than that in the Greek Ionian Sea (Anon., 2001).

\section{ACKNOWLEDGEMENTS}

The author expresses his appreciation to Mrs. C. Mytilineou for providing the samples and the translation of the summary. The surveys were part of the INTERREG-II Greece-Italy. Thanks are also due to the anonymous reviewers for their critical suggestions. Dr. A. Conides is gratefully thanked for improving the English of the manuscript and $\mathrm{Mr}$. Kavadas S. for his technical assistance.

\section{REFERENCES}

Abelló, P., A. Abella, A. Adamidou, S. Jukic-Peladic, P. Maiorano and M.T. Spedicato. - 2002. Geographical patterns in abundance and population structure of Nephrops norvegicus and Parapenaeus longirostris (Crustacea: Decapoda) along the European
Mediterranean coasts. Sci. Mar., 66(Suppl. 2): 125-141.

Anonymous. - 1999. Developing deep-water fisheries: data for their assessment and for understanding their interaction with and impact on a fragile environment. EC FAIR project CT 950655. Final Report of Partner No 6. National Centre for Marine Resources (Greece), 144 pp.

Anonymous. - 2001. Exploration of the renewable marine biological resources in the deep waters (INTERREG II). Final Report, vol. IV, $281 \mathrm{pp}$

Anonymous. - 2003. Exploration of pristine red shrimp resources and comparison with exploited ones in the Ionian Sea (RESHIO). Final Report, 209 pp.

Ardizzone, G. D., M.F. Gravina, A. Belluscio and P. Schintu. 1990. Depth-size distribution pattern of Parapenaeus longirostris (Lucas, 1846) (Decapoda) in the Central Mediterranean Sea. J. Crustacean Biol., 10(1): 139-147.

Arrobas, I. and A. Ribeiro Cascalho. - 1982. Some aspects of the fishery and biology of Parapenaeus longirostris off Portuguese coast. ICES, C.M. 1982/K: 5.

Audouin, J. - 1965. Répartition bathymétrique des crevettes sur les côtes algériennes entre les îles Zaffarines et les îles Habibats. Comm. Int. Explor. Sci. Mer. Médit., P.-V. Reun., 18: 171-174.

Bowman, R.E. and E.W. Bowman. - 1980. Diurnal variation in the feeding intensity and catchability of silver hake (Merluccius bilinearis). Can. J. Fish Aquat Sci., 37: 1565-1572.

Burukovsky, R.N. - 1969. On the bathymetric distribution and feeding of the shrimp, Parapenaeus longirostris (Lucas). ICES CM 1969/K: 6 .

Cartes, J.E. - 1995. Diets of, and trophic resources exploited by, bathyal penaeoidean shrimps from the Western Mediterranean. Mar. Freshwater Res., 46: 889-896.

Cartes, J.E. and F. Sardà. - 1989. Feeding ecology of the deepwater aristeid crustacean Aristeus antennatus. Mar. Ecol. Prog. Ser., 54: 229-238.

Cartes, J.E. and P. Abelló. - 1992. Comparative feeding habits of polychelid lobsters in the Westerm Mediterranean deep-sea communities. Mar. Ecol. Prog. Ser., 84: 139-150.

Cervantes, A. and R. Goñi. - 1986. Resumen de los datos de base y parámetros biológicos de la pesquería de gamba en la división 34.1.1. de C.E.C.A.F. COPACE/PACE Ser. 86/33, 157-164.

Cervantes, A., I. Sobrino, A. Ramos and L. Fernández. - 1991. Descripción y análisis de los datos de las pesquerías de merluza y gamba de la flota española que faenó al fresco en África noroccidental durante el período 1983-1988. Inf. Téc. Inst. Esp. de Oceanogr., 111: 85 pp.

Company, J.B. - 1995. Estudi comparatiu de les estratègies biològiques dels crustacis decapods de la Mar Catalana. PhD thesis, Univ. de Barcelona.

Crosnier, A., A. Fontana, J.C. Le Guen and J.P. Wise. - 1970. Ponte et croissance de la crevette Peneide Parapenaeus longirostris (Lucas) dans la region de Pointe-Noire (Republique du Congo). Cah. ORSTOM, Ser. Oceanogr., 8: 89-102.

Crosnier, A. and J. Forest. - 1973. Les crevettes profondes de l'Atlantique oriental tropical. ORSTOM, Faune Tropicale, 19: 409 pp.

Dall, W.B., J. Hill, P.C. Rothlisberg and D.J. Sharples. - 1990. The biology of the Penaeidae. Adv. Mar. Biol., 27, 489 pp.

De Ranieri, S., M. Mori and M. Sbrana. - 1998. Preliminary study on the reproductive biology of Parapenaeus longirostris (Lucas) off the northern Tyrrhenian Sea. Biol. Mar. Medit., 5(1): 710-712.

D’Onghia, G., A. Matarrese, P. Maiorano and F. Perri. - 1998. Valutazione di Parapenaeus longirostris (Lucas, 1846) (Crustacea, Decapoda) nel Mar Ionio. Biol. Mar. Medit., 5(2): 273-283.

Dos Santos, A. - 1998. On the occurrence of larvae of Parapenaeus longirostris (Crustacea: Decapoda: Penaeoidea) off the Portuguese coast. J. Nat. Hist., 32: 1519-1523.

Freire, J. and E. González-Gurriarán. - 1995. Feeding ecology of the velvet swimming crab Necora puber in mussel raft areas of the Ría de Arousa (Galicia, NW Spain). Mar. Ecol. Prog. Ser., 119: 139-154.

Froglia, C. - 1982. Contribution to the knowledge of the biology of Parapenaeus longirostris (Lucas) (Decapoda, Penaeidea). Quad. Lab. Tecnol. Pesca, 3 (2-5): 163-168.

Holthuis, L.B. - 1980. FAO species catalogue. Vol. 1. Shrimps and prawns of the world. An annotated catalogue of species of interest to fisheries. FAO Fish. Synop., 125(1): 261 pp.

Hyslop, E.J. - 1980. Stomach content analysis. A review of methods and their application. J. Fish Biol. 17: 411-429. 
Jutkins, D.C. and A. Fleminger. - 1972. Comparison of foregut contents of Sergestes smiles obtained from net collections and albacore stomachs. Fish. Bull. U.S. 70: 217-223.

Kapiris, K., C. Mytilineou, P. Maiorano, S. Kavadas and F. Capezzuto. - 2002. Abundance and bathymetrical distribution of Parapenaeus longirostris in the Greek Ionian Sea. Fourth European Crustacean Conference, Poland. Book of abstracts: 54 .

Koukouras, A. and M. Kattulas. - 1974. Benthic fauna of the Evvoia coast and Evvoia

Gulf. III Natantia (Crustacea, Decapoda). Annals Fac. Phys. \& Mathem., Univ. Thessaloniki 14: 369-383.

Labropoulou, M. and I. Kostikas. - 1999. Patterns of resource use in deep-water decapods. Mar. Ecol. Prog. Ser., 184: 171-182.

Lagardère, J.P. - 1972. Recherches sur l'alimentation des crevettes de la Pente Continental Marocaine. Tethys, 3: 655-675.

Lagmari, H., A. Chentoufi, A. Idelhaj and A. Chafik. - 2001. Length frequency distributions study and spawning period of deepwater pink shrimp Parapenaeus longirostris (Lucas, 1846) of the Moroccan North Atlantic. J. Rech. Oceanogr., 26(4): 42-49.

Lembo, G., T. Silecchia, P. Carbonara, M. Contegiacomo and M.T. Spedicato. - 2000. Localization of nursery areas of Parapenaeus longirostris (Lucas, 1846) in the central-southern Tyrrhenian Sea by geostatistics. Crustaceana, 73(1): 39-51.

Levi D., M.G. Andreoli and R.M. Giusto. - 1995. First assessment of the rose shrimp Parapenaeus longirostris (Lucas, 1846), in the Central Mediterranean. Fish. Res., 21: 375-393.

Massuti, M. - 1963. La pêche des Crustacés aux Baleares (Méditerrannée occidentale) et dans l'Atlantique sud (Golfe de Cadix). C.G.P.M. Débats et Doc. tech., Vol. 7, Doc. 14: 191-202.

Maurin, C. - 1960. Les crevettes profondes du littoral français de la Méditerranée. Répartition selon la profondeur. Notes biométriques. Comm. Int. Explor. Sci. Mer. Médit., P.-V. Reun., 15: $147-154$

Maynou, F. and J.E. Cartes. - 1997. Field estimation of daily ration in deep-sea shrimp Aristeus antennatus (Crustacea: Decapoda) in the western Mediterranean. Mar. Ecol. Progr. Ser., 154: 191-196.

Morato, T., R. Serrao Santos and J.P. Andrade. - 2000. Feeding habits, seasonal and ontogenetic diet shift of blacktail comber, Serranus atricaudata (Pishes: Serranidae), from the Azores, norteastern Atlantic. Fish. Res., 49: 51-59.

Mori, M., P. Belcari and F. Biagi. - 1986 Distribuzione e sex-ratio di Parapenaeus longirostris (Lucas) nel Tirreno Settentrionale. Nova Thalassia, 8(3): 623-625.

Mori, M., P. Sartor and F. Biagi. - 2000. Diet of adult females of Parapenaeus longirostris (Crustacea, Decapoda) in the Northern Tyrrhenian Sea (Western Mediterranean). Atti Soc. Tosc. Sci. Nat. Mem., Serie B, 107: 7-10.

Nouar, A. and C. Maurin. - 2001. Nature and typical populations on the characteristic facies of substratum of Parapenaeus longirostris (Lucas, 1846) along the Algerian coast. Crustaceana, 74(2): 129-135.

Olaso, I. - 1990. Distribución y abundancia del megabentos invertebrado en fondos de la plataforma Cantábrica. Publ. Espec. Inst. Esp. Oceanogr., 5: 128 pp.

Orsi Relini, L. - 1973. I crostacei batiali del Golfo di Genova nelle osservazioni di Alessandro Brian e nelle condizioni attuali. Atti $V$ Congr. Naz. Soc. It. Biol. Mar. - Ed. Salentina - Nardò: 25-40.

Pérès, J.M. - 1985. History of the Mediterranean biota and the colonization of the depths. In 'Key Environments: Western Mediterranean'. Ed. R. Margalef.) pp. 198-232. (Pergamon: New York).

Pestana, G. - 1991. Stock assessment of deep water rose shrimp (Parapenaeus longirostris) from the southern Portugal (ICES Division Ixa). ICES Doc. C.M. 1991/K: 46. 29 pp.

Politou, C.-Y., M. Karkani and J. Dokos. - 1998. Distribution of Decapods caught during MEDITS surveys in Greek waters. In: J.A. Bertrand and G. Relini (eds.), Demersal resources in the
Mediterranean, Proceedings of the Symposium held in Pisa, 18-21 March 1998, Actes des Colloques, 26: 196-207. IFREMER, Plouzané

Ribeiro Cascalho, A. - 1988. Biologia, ecologia e pesca dos peneídeos de profundidade Parapenaeus longirostris (Lucas) e Aristeus antennatus (Risso) da costa portuguesa. Dissertação para provas de acesso à categoria de Investigador Auxiliar, INIP, $171 \mathrm{pp}$

Ribeiro Cascalho, A. and I. Arrobas. - 1983. Further contributions to the knowledge about biology and fishery of Parapenaeus longirostris (Lucas, 1846) of South Portuguese coast. ICES CM 1983/K: 26

Ribeiro Cascalho, A. and I. Arrobas. - 1987. Observations on the biology of Parapenaeus longirostris (Lucas, 1846) from the south Portuguese coast. In: III Colloquium: Crustacea Decapoda Mediterranea. Inv. Pesq., 51(Suppl. 1): 201-212.

Shannon, C.E. and W. Weaver. - 1963. The mathematical theory of communication. Press Urbana. Univ. Illinois.

Sobrino, I. - 1988. Biología y pesca de la gamba blanca (Parapenaeus longirostris, Lucas, 1846) en el Atlántico nororiental. $\mathrm{PhD}$ thesis, Univ. Sevilla, $218 \mathrm{pp}$.

Sobrino, I. and L. Fernández. - 1991. Resultados obtenidos para la gamba (Parapenaeus longirostris, Lucas, 1846) en la campaña "Guinea-90". FAO CECAF/ECAF Ser., 91/55: 63-85.

Sobrino, I. and T. García. - 1991. Análisis y descripción de las pesquerías de crustáceos decápodos en aguas de la República Islámica de Mauritania durante el periodo 1987-1990. Inf. Téc. Inst. Esp. Oceanogr., 112: 38 pp.

Sobrino, I. and T. García. - 1992a. Análisis y descripción de la actividad de la flota española en las pesquerías de crustáceos decápodos profundos en aguas de la República de Senegal durante el periodo 1987-1990. Inf. Téc. Inst. Esp. Oceanogr., 125: $37 \mathrm{pp}$.

Sobrino, I. and T. García. - 1992b. Análisis y descripción de las pesquerías españolas de crustáceos decápodos en aguas de la República de Guinea Bissau durante el periodo 1987-1991. Inf. Téc. Inst. Esp. Oceanogr., 135: 38 pp.

Sobrino, I. and T. García. - 1994. Biology and fishery of the deepwater rose shrimp Parapenaeus longirostris (Lucas, 1846) from the Atlantic Moroccan coast. Sci. Mar., 58(4): 299-305.

Sobrino, I., M.P. Jiménez, F. Ramos and J. Baro. - 1994. Descripción de las pesquerías demersales de la región suratlántica española. Inf. Téc. Inst. Esp. Oceanogr., 151: 76 pp.

Sobrino, I. and E. de Cárdenas. - 1996. Análisis de los resultados obtenidos para la Gamba Blanca (Parapenaeus longirostris, Lucas, 1846) durante la Campaña "Angola 8911". In: O. Llinás, J.A. González and M. Rueda (eds.), Monogr. Inst. Canario Cienc. Mar., pp.356-375. Telde, Las Palmas de Gran Canaria

Sobrino, I. T. Garcia and J. Baro. - 2000. Trawl gear selectivity and the effect of mesh size on the deep-water rose shrimp (Parapenaeus longirostris, Lucas, 1846) fishery off the gulf of Cadiz (SW Spain). Fish. Res., 44: 235-245.

Sokal, R. R. and Rohlf - 1981. Biometry, 2nd ed. W. H. Freeman and Co., San Francisco.

Spedicato, M. T., G. Lembo, T. Silecchia and P. Carbonara. - 1996 Distribuzione e biologia di Parapenaeus longirostris (Lucas, 1846) nel Tirreno centro- meridionale. Biol. Mar. Medit., 3(1): $579-581$.

Stamatopoulos, C. -1993 . Trends in catches and landings. Mediterranean and Black Sea fisheries: 1972-1991. FAO Fisheries Circular, No 855.4, 177 p.

Tom, M., M. Gorem and M. Ovadia. - 1988. The benthic phases of life cycle of Parapenaeus longirostris (Crustacea, Decapoda, Penaeidae) along the Mediterranean coast of Israel. Hydrobiologia, 169(3): 339-352.

Scient. ed.: F. Sardà 